Проф. др Мирјана Теодосијевић

Филолошки факултет у Београду 8 811.163.41'373.45 mirjanateo@gmail.com https://doi.org/10.18485/ai_andric.2018.ch15

\title{
УЗ МОСТОВЕ ОСТАЛА ЈЕ И ЋУПРИЈА
}

Рад представља прилог проучавању турцизама у стваралаштву Иве Андрића кроз језичку анализу њихове употребе. Приче и романи који се односе на период под владавином Турака Османлија не би имале ту аутентичност и веродостојност да Андрић своје реченице није обогатио и турцизмима. За Андрића турцизми нису само појмови, него и симболи који носе преносна значења што уноси динамику у његову уметничку интерпретацију. Ауторов најпознатији турцизам је несумњиво „ћуприја“ - грандиозни мост који је дао посебан печат његовом уметничком стваралаштву.

Кључне речи: Иво Андрић, турцизми, ћуприја, мост, Турци.

Приче из далеке прошлости којима обилује књижевни опус Иве Андрића сигурно не би имале ону изворну аутентичност и веродостојност да Андрић своје реченице није обогатио и турцизмима. Читава симболика садржана је у тим речима и појмовима којима је тако убедљиво дочарао историјски оквир владавине Турака Османлија у његовом завичајном поднебљу.

Приликом уручивања Нобелове награде Иви Андрићу 10. децембра 1961. године у Стокхолму, др Андерс Естерлинг, члан Шведске академије наука, је, између осталог, рекао: „На дипломи Ваше награде написано је да Вам се Нобелова награда додељује 'за епску снагу' 
којом сте Ви обликовали мотиве и судбине из историје Ваше земље“. Да би успешно „обликовао мотиве и судбине“ народа под влашћу Османлија - Турака, што је у то време био уобичајен назив не само за Османлије већ и за босански муслимански свет, он је користио турске речи у облику и значењу у коме су се употребљавале у Босни и Херцеговини у 19. веку. Најлепше примере њихове употребе налазимо управо у Андрићевом изузетном књижевном стилу и језику. Јер, за њега турцизми нису само голи појмови него и симболи пуни преносних значења која уносе врхунску динамику у његову уметничку интерпретацију.

С обзиром да је један део свога најранијег живота и школовања провео у Вишеграду и Сарајеву, он је од ране младости, попут својих суграђана, усвојио неке турцизме као свакодневну лексику а које ће, касније, маестрално уткати у своје књижевно стваралаштво.

Људи и средина у којој је одрастао оставиће велике трагове у Андрићевом животу и биће најзначајнија инспирација за његово уметничко стваралаштво. Па тако, док се као дечкић играо са друговима поред реке и на мосту који се налазио недалеко од теткине и течине куће, код којих је живео док није завршио основну школу, Дрина и мост ће постати надахнуће, извор за писање његових „турских прича“, а пре свега, ремек-дела На Дрини ћуйрија. У том делу је овековечен и пишчев несумњиво најпознатији турцизам - ћуприја, који пркосно доминира и у самом наслову славног романа.

Лексички, сама реч ћуйрија је изведена од турске речи köprü која у турском језику има значење „мост“. Међутим, овим турцизмом се у српском најчешће означава „мали мост“, што поткрепљује и изрека „Ко не плати на мосту, платиће на ћуприји“. 
Имајући у виду српско значење турцизма „ћуприја“ остаје упитно зашто је Андрић грандиозну творевину Мехмед-паше Соколовића, вишелучни велелепни мост над Дрином назвао једноставно ћуприја? Истовремено, једнолучни мост изнад Жепе, који се простире између две стене, назвао је - мостом.

Одговор на ове недоумице највероватније се скрива у Андрићевој симболици, оној којом је тако вешто испреплетао „исток“ и „запад“ остављајући при томе и једној и другој страни властита смисаона обележја. Довољно је само у наслову дела видети да ли је „мост“ или „ћуприја“, па поуздано знати о ком времену писац приповеда. Али, Андрићева „ћуприја“ није само асоцијација за „турско доба“, већ је она и носилац улоге главног јунака његовог најпознатијег романа, „лик“ око кога је све у узрочно-последичној вези. Самим тим, ова „ћуприја“ је значењски више од „моста“ и ни у ком случају није му прави синоним.

Навешћемо још једно запажање у вези са овим турцизмом. Као што је познато, на крају свих издања Андрићевих дела налази се „Речник турцизама, провинцијализама и неких мање познатих речи“ непознатих састављача. Чак је и на крају турског превода романа дат списак турцизама који се користе у српском оригиналу (Andriç 2010: 351-354). Интересантно је то што се ни у једном од њих, чак ни у речнику на крају романа На Дрини ћуӣрија, не наводи турцизам ћуприја (Андрић 1963: 350). Из тога се може закључити да се турцизам ћуприја асимиловао у савремени српски језик као архаизам. Међутим, управо овај турцизам је, преко Андрићевог романа, остао да живи као симбол људских судбина, спајања и раздвајања. Па тако, и поред свих мостова, ћуприја остаје за сва времена као неуништива, смисаона творевина славног писца. Управо онако како је то и сам писац желео. 
Сећања на овај мост - ћуприју из најранијег детињства, изнедриће код писца љубав према мостовима уопште и инспирисати га да напише приповетку „Мост на Жепи“ (објављена 1928), а 1933. године у божићном броју Политике запис „Мостови“: „Од свега што човек у животном нагону подиже и гради, ништа није у мојим очима боље и вредније од мостова. Они су важнији од кућа, светији, општији од храмова. Свачији и према свакоме једнаки, корисни, подигнути увек смислено, на месту на коме се укршта највећи број људских потреба, истрајнији су од других грађевина и не служе ничем што је тајно или зло“.

Анализирајући турцизме у делима Иве Андрића забележили смо њихов далеко већи број од оног наведеног у речницима на крају дела. Рецимо, док је у речнику на крају романа На Дрини ћуирија наведено око 200 турцизама, ми смо забележили 417, од којих се један број више пута понавља у делу. Слично је и када је реч о Травничкој хроници где смо ексцерпирали 467 турцизама. Природно је да број турцизама варира у зависности од теме дела као и његове дужине. Примера ради, наводимо оријентациони број турцизама у појединим Андрићевим делима / приповеткама: „Мост на Жепи“ 33 ; „Прича о везировом слону“ 98 ; „Госпођица“ 62; „Жеђ)“ око 150; „Деца“ око 110; „У завади са светом“ 122; „Кућа на осами“ око 40; „Омерпаша Латас“ 267; „Немирна година“ 313 ; „Мара Милосница“ 90; „Јелена, жена које нема“ око 110; „Пут Алије Ђерзелеза“ 110; „Турске приче“ 312, „Проклета авлија“, 112; „Кућа на осами“, 119. Тачан број турцизама којима обилује дело Иве Андрића још није утврђен, али је сигурно да су се, захваљујући подоста Андрићевим делима, многи турцизми сачували у српском језику до данашњих дана потврђујући тако да су трајно уткани у српску лексику. 
У свом есеју „Исток у приповеткама Иве Андрића“ Исидора Секулић наводи да „у приповеткама Иве Андрића има много Истока, и има га од сваке врсте, стравичног, мрачног, поетичног, шаљивог, мудрог. Сарајлија, 'дете са Истока', Андрић има бескрајно и врело интересовање за исламски елемент који је толико времена био господар и судбина његова завичаја, за све примитивне, сурове, грозне, а уз то загонетне и живописне типове из тог старог, турског времена Босне“ (Секулић 1964: 126).

Да би што пластичније, верније и сликовитије описао тај у то време убоги Исток, који је био и његов завичај, Андрић користи читаву лепезу турцизама, од којих су многи већ одавно изашли из употребе. Мирјана Теодосијевић дели турцизме на следећи начин: „Историзми - речи које су престале да се употребљављају престанком употребе предмета и појава које су означавале као на пример: абаџија, кириџија, ферман, нахија, који се јављају у историјским уџбеницима, лирско-епској поезији, књижевним делима и за које се обавезно даје тумачење; Архаизми - речи које су престале да се употребљавају у савременом језику зато што су их замениле друге речи за означавање истих предмета, појава, особина као што су на пример: терзија/кројач, зејтин/уље, бакалница/продавница; Турцизми који су се потпуно асимиловали. У ову групу спадају речи за које не постоји адекватна замена (као што су на пример: шећер, кафа, мердевине, маказе), као и оне које су се потпуно одомаћиле иако за њих постоји замена (јок, ђубре, парче)“ (Теодосијевић 2010: 57-58).

Друга подела турцизама би била према њиховом значењу, то јест према садржају. Ово разврставање се изводи на основу постојеће грађе и обухвата различите термине као што су: религијски, називи верских објеката, предмети покућства, одећа и обућа, јела и пића, 
административни и војни термини, називи оруђа, воћа, поврћа и зачина, топоними, апстрактне и друге именице, узвици и још многе турске речи које су ушле у српски језик посредством Турака Османлија и задржале се у употреби како у говорном језику тако и у свим језичким стиловима.

Из богатог књижевног опуса Иве Андрића ексцерпирали смо турцизме којима обилују и разврстали их, за ову прилику, у следеће категорије како бисмо само_наговестили скривено лексичко богатство његове поетике. Анализа свих других категорија захтева дугорочније истраживање. То су:

\section{а. Муслиманска имена и титуле}

У делима Иве Андрића наилазимо на читаву галерију ликова са муслиманским именима. То су Бехџет, Хамдија, Хамза, Хусо, Хусреф, Ибрахим, Ибро, Исмаил, Муних, Мурат, Муса, Мустафа, Раиф, Сулејман, Тахир и друга. Уз многа имена дате су њихове титуле или друге лексеме за ословљавање. Приликом писања војних и других титула уз имена, Андрић их пише у изворном облику, то јест додаје их иза личног имена као што се користе у турском језику:

сулйан (тур. sultan - султан, падишах). Џем султан (у значењу султан Џем). У турском језику титула сулйан употребљена иза имена значи сулйанија. везир (тур. vezir - највиша титула у државној хијерархији османлијске државе; министар, гувернер једне покрајине, управник вилајета). Везир Мехмед Ружди-паша. Ово је једна од ретких титула која се ставља испред личног имена.

йama (тур. paşa - висока војна и цивилна титула у Оc- 
манлијском царству. Мехмедпаша (у значењу паша Мехмед), Омерпаша Латас (у значењу паша Омер), Даутхоџа (у значењу хоџа Даут), Алихоџа, (хоџа Алија), Али-паша (у значењу паша Алија). У савременом турском језику значи генерал и адмирал.

aīa (тур. ăga - звање руководећих лица у Османлијском царству; газда, добростојећи грађанин). Латифага (у значењу ага Латиф), Ахметага (у значењу ага Ахмет), Смајилага (у значењу ага Смаил), Диздарага (у значењу ага Диздар).

$\delta e \bar{\imath}$ (тур. bey - господар, заповедник, поглавар племена; у савременом турском језику значи іосйоguн). Мустајбег (у значењу бег Мустај), Шемсибег (у значењу бег Шемси). Мада је титула $\delta е \overline{~ п л е м и ћ к а ~}$ титула, она се често додаје на мушка муслиманска имена из поштовања, у значењу їосӣоgин што је врло чест обичај у босанско-херцеговачким градовима и селима.

eøенguja (тур. efendi - господин, господар; титула муслиманског свештеника или

верски образованог муслимана). Џелалудин-ефендија, Омер-ефендија.

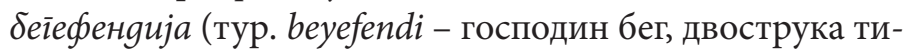
тула којом се ословљавају бегови који су светски или верски образовани). У савременом турском језику се користи за ословљавање непознатих мушкараца.

челеби (тур. çelebi - господин, племенити; старешина бекташијског и мевлевијског дервишког реда). Челеби Хафиз.

хоиа (тур. hoca - муслимански свештеник, вероучитељ, професор у медреси). Хоџа из Бихаћа. 


\section{б. Изрази и узвици}

Само неко ко је одрастао у муслиманској средини може да тако тачно користи узвике и изразе, од којих се већина губи из употребе у српском, али су и даље присутни у савременом турском језику. Наводимо неколико примера из „Турских прича“ и Травничке хронике:

Ачкосум, магарче! (тур. aşk olsun - како си могао да то урадиш, то није лепо од тебе; браво)

Аферим, кењчино! (тур. aferin - браво)

Накашљао се и ударио руком по кољену и два пут је викнуо за њом: - Аман!“ (тур. aman - побогу, забога)

Aсли и није он човјек ко што су други људи. (тур. aslinda - заиста, сва је прилика)

Бог ти на помоћ, бег-ефендија; ејсаguле! - викао је калуђер одмичући брзо (тур. ey saatiyle - у добри час пошао). Поздрав при растанку који изговара онај који испраћа. Овај израз се више не користи у савременом турском језику. Замењен је изразом güle güle што значи „довиђења; иди смејући се“, „срећно“, „све најбоље“.

Cикиеер, море, и ти и кадија! (тур. siktir - напоље, губи се, торњај се). У савременом турском језику реч siktir има вулгарно значење.

Машалах, машалах! Не буди му урока! (тур. maşallah да није урока). У овој реченици писац употребљава турски израз maşallah упоредо са преводом на српски језик, чиме се добија појачано значење.

Излази, рсузе! Ajge, aj-gee! (тур. hırsiz - lopov). Узвик „ајде“ (тур. haydi, hadi) је врло фреквентан у турском језику.

Кренућеш ти, акобогда, инщалах, кренути, јакако, па ће се видети и чути у пола свијета шта је и ко је Мурат и од каквог је соја и кољена. (тур. inşallah 
- акобогда). Узвик је дат у оригиналу и са преводом. У савременом језику има широку употребу. Турци уз све што треба да се уради или што се планира кажу „иншалах“.

Јок јок ианум! (тур. сапıт - душо моја). Именица сапıт се често користи у савременом турском језику за ословљавање женских и мушких особа, деце и одраслих. Такође се користи и узречица „јок џанм“ (тур. yok canım) којом се изражава чуђење: ма није вальяа! стиварно?.

„Ха држи га, земљо!

Повуци, потегни!

Jаaлах!“ (тур. ya Allah - О боже! Боже помози!) Овај узвик се користи и у савременом турском језику који је, иначе, богат фразеологизмима са лексемом Allah.

Изрази, узвици и фразеологизми турског порекла чија се значења могу разумети једино у одговарајућем контексту, а које је Андрић вешто и зналачки користио у свом језичком исказу, још су један показатељ његовог вансеријског стваралачког дара.

\section{в. Термини занимања}

Већина занимања која су постојала у „турско доба“ данас више не постоје, тако да и њихови називи спадају у категорију историзама.Значења тих занимања су најчешће дата у речнику на крају сваког дела. Овде су обрађена занимања која се само спомињу у приповеткама „Пут Алије Ђерзелеза“ (ПАЂ) и „Мост на Жепи“ (МНЖ).

арачлија (тур. haraçсı - онај који убира харач, порезник). „Суљага Диздар, са тројицом арачлија који је путовао службено.“ (ПАЂ, 11) 
apia $\bar{u}$ (тур. rgat - надничар, радник који ради под тешким условима). „Мост су градили тесари, а пут

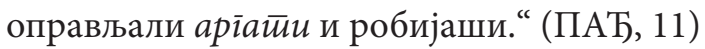

aскер (тур. asker - војник). „Дешавало се послије бурних вечери, кад би аскери или сарајски момци викали..." (ПАЂ, 32)

биюеција (тур. binici - јахач, коњаник). „На Увцу је Ђерзелез прескочио ријеку и побио коња тако да су имали сви бинјещије и прибојски џамбаси посла.“ (ПАЂ, 18)

guзgap (тур. dizdar - заповедник тврђаве или утврђеног града). „Суљага Дизgар, са тројицом арачлија који је путовао службено." (ПАЂ, 11)

gyћaнщuја (тур. dükkancı - ситан трговац, власник мање радње). „А gyћаниије га све више испитују о неимару и његовом животу..." (МНЖ, 166)

измећарица (тур. hizmetkar - слуга + ср. -ица; служавка, слушкиња). „една старица, измећарица, смежураних руку, кумала је ситним пјеском авлијска врата..." (ПАЂ, 29) У турском језику не постоји категорија рода, тако да је ово хибридни турцизам изведен од турске речи и српског суфикса.

кaguja (тур. kad - шеријатски судија). „Повјешаће нас каguja све." (ПАЂ, 26)

кириција (тур. kiracı - онај који с коњима и колима превози робу уз награду). „Два трговца из Ливна и кирииије им.“" (ПАЂ, 12)

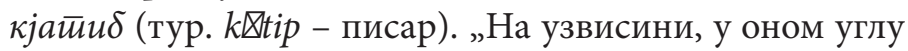
што га чине Дрина и Жепа, сагради брвнару -

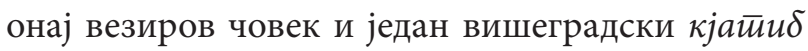
су ми били тумачи - и у њој је становао.“ (МНЖ, 163) Овај турцизам је идентичан са турским изговором. У литератури се чешће срећу облици

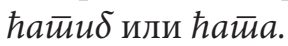


муалим (тур. muallim - учитељ, наставник). „Донесоше ми молбу једног младог, а ученог цариградског муалима..." (МНЖ, 167)

иезевенкуша (тур. pezevenk - подводач; подводачица). „Млади Бакаревић им предложи да зовну Ивку Гигушу, стару и познату иеезевенкущу с Бистрика..." (ПАЂ, 33)

росӣuja (тур. orospu - проститутка). „Не гађај се, Земко, росиичјо..." (ПАЂ, 27)

салеঠиија (тур. salepçi - продавац салепа, топлог напитка направљеног од корена каћуна куваног у млеку који се пије зими). „Три Арнаута салебиије.“ (ПАЂ, 12)

сомунgщија (тур. sотипси - продавац сомуна, округлог хлеба). „Једно поподне испребијаше од чамотиње и зловоље неког сомуниију, хришћанина, што је прошао пушећи.“ (ПАЂ, 33)

хазнаgар (тур. hazinedar - благајник, чувар блага). „Њега најми везиров хазнаgар и посла са двојицом дворских људи у Босну.“ (МНЖ, 163)

xajgyк (тур. haydut - одметник од власти, лопов, друмски разбојник). „Хајдуци!“ (ПАЂ, 28)

ханција (тур. hancl - онај који држи хан било да је власник или закупац). „Ханщија се већ прибојавао скандала, али га Фочак са објешењачким, надмоћним смешком зауставља." (ПАЂ, 14)

заййија (тур. zaptiye - редар, полицајац). „Имали су тескеру од паше из Сарајева и заййију да им иде на руку, али су се држали повучено и изгледали отмено и сумњиво.“(ПАЂ, 12)

чаліиција (тур. çalgıcı - свирач). „Чуло се само да је починио много лудости због удовице једног ушћупског трговца и да га је огулила нека Јеврејка што је ходила с чаліицијама из Селаника.“ (ПАЂ, 27) 
цам $\delta a c$ (тур. сambaz - актобата; препродавац коња). „На Увцу је Ђерзелез прескочио ријеку и побио коња тако да су имали сви бинјеџије и прибојски цамбаси посла.“ (ПАЂ, 18)

Мада му је оријент често био тема размишљања, извор инспирације и писања - „Азија у мојој души“, како је написао у посвети Исидори Секулић поклањајући јој На Дрини ћуйрију 1945. године, Андрић је минимално користио турцизме у својој личној преписци, критичким и есејистичким текстовима. Мишљења смо да би приликом превођења Андрићевих дела са оријенталном тематиком на друге језике требало да се у језику превода сачувају турцизми као залог прошлости који својом богатством и разноврсношћу доприносе аутентичности Андрићевог приповедања.

\section{Извори и литература}

Andriç, İvo. Drina Köprüsü. Çevirenler Hasan Ali Ediz, Nuriye Müstakimoğlu. İstanbul: İletişim Yayınları, 13. Baskı, 2010

Андрић, Иво. На Дрини ћуйрија. Београд: Просвета, 1963

Andrić, Ivo. Turske priče. Beograd: Laguna, 2011

Поповић, Радован. „Животопис Иве Андрића - прилог за биографију“. Политика, петак 7. март 1980, стр. 21

Sabrana djela Ive Andrića. Sarajevo: Свјетлост, 1988

Sekulić, Isidora. Iz domaćih književnosti I. Subotica: Minerva, 1964

Škaljić, Abdulah. Turcizmi u srpskohrvatskom-hrvatskosrpskom jeziku. Peto izdanje, Sarajevo: Svjetlost, 1985

Теодосијевић, Мирјана. „Улога библиотекара у тумачењу позајмљеница у српском језику - на примерима“. Школска библиотека и настава језика и књижевности. Књ. 1. Београд: Филолошки факултет, 2010, 55-61. 
Mirjana Teodosijević

\section{ALONGSIDE OF ALL THE BRIDGES THERE REMAINS THE "ĆUPRIJA“}

\section{Summary}

The stories from the distant past, which are found in abundance in the literary opus of Ivo Andric, would not have such striking authenticity and credibility had he not thus enriched his sentences with Turkish loanwords. An entire array of symbolism is contained in the words and notions that he had used to depict the times he was writing about. Owing to his style, many Turkish loanwords have been preserved in the Serbian language up to this very day. The most beautiful and outstanding examples of their usage are to be found in his exceptional literary style and language. For Andric, Turkish loanwords do not only represent words and notions, rather they are also symbols bearing and transmitting metaphorical meaning, which introduces a much greater dynamic into his creative interpretation. The author's most famous Turkish loanword undoubtedly is "Ćuprija" - a grandiose bridge that gave a special imprint to his artistic creation.

This research paper represents a modest contribution to the study of Turkish loanwords in the creative work of Ivo Andric through linguistic analysis of their usage. 